\title{
ACTIVITY OF AGROHOLDINGS IN THE WORLD MARKET OF AGRICULTURAL PRODUCTS IN THE CONTEXT OF GLOBALIZATION
}

\author{
Vitalina Babenko \\ Doctor of Economic Sciences, Professor \\ V. N. KarazinKharkiv National University, \\ 6, Svobody sq., Kharkiv, Ukraine, 61022 \\ e-mail: vitalinababenko@karazin.ua; ORCID: http://orcid.org/0000-0002-4816-4579 \\ Scopus Author ID: 56658371300; ResearcherID: E-6521-2018 \\ Vadim Sidorov \\ PhD, Professor \\ V. N. KarazinKharkiv National University, \\ 6, Svobody sq., Kharkiv, Ukraine, 61022 \\ e-mail: v.i.sidorov@karazin.ua; ORCID: https://orcid.org/0000-0002-5655-2221 \\ Ruslan Savin \\ Postgraduate Student \\ V. N. KarazinKharkiv National University \\ 6, Svobody sq., Kharkiv, Ukraine, 61022 \\ e-mail: irtb@karazin.ua; ORCID: https://orcid.org/0000-0003-4634-0660
}

\begin{abstract}
Modern processes of reforming the agroindustrial complex of Ukraine in the conditions of globalization of world economic processes in the agricultural market requires from the domestic agroholdings the improvement and rational management of production activity. So the tendencies of development of agroholdings and other agroformations in modern socio-economic conditions are relevant. In order to study the mechanism of their development, models of interconnection between the components of production of the main types of products of agricultural holdings and the availability of agricultural raw materials are constructed. The main approaches are the multivariate regression modeling of the dependence of production of agricultural holdings on components of agricultural production. The subject of the study in the article is the development of the agroholdings. The goal is researching of the tendencies of development of agroholdings and other agroformations in modern socio-economic conditions. Objectives: research of dynamics of the development of agroholdings of Ukraine in terms of its components in the conditions of globalization of world economic processes in the market of agricultural products.

Common scientific methods are used: system analysis for to determine the peculiarities of the development of the agro-industrial production in Ukraine; the regression analysis for calculating of the dependence of production of agricultural holdings on components of agricultural production. The following results: on the basis of the analysis of the dynamics of changes in the main indices of domestic agricultural production were obtained analytical interdependence of factors influencing on development of agroholdings. Conclusions: the multivariate regression model of the dependence of production of agricultural holdings on components of agricultural production is calculated; obtained researchings are expedient to use in foreign economic activity as recommendations for definition of the strategy of Ukraine on the world market of agricultural products.
\end{abstract}

Key words: agroholding, world economy, agroindustrial production, agricultural products, developmental factors, regressive model.

\section{Introduction.}

The most relevant task of effective planning and management of the activities of agroholdings was after the ratification of the Ukraine-European Union Association with the delay in establishing Ukraine-EU free trade zone. The EU`s regulations, directives, decisions and recommendations, which are included in the annexes to the Agreement, are the part of the legal standards to be fulfilled by the Ukrainian side and require agroholdings to produce innovative products with high quality consumer characteristics, to use innovative technologies for in-depth processing of agricultural raw materials and their storing and other elements of agricultural management. The implementation of these requirements in order to raise the domestic agrarian business to a higher level, in particular of European standards, of stabilization and development of agricul- tural production, requires the development of the agricultural industry, the formation of new approaches and mechanisms for its implementation.

Domestic agroindustrial processing industry has a significant potential, which is able to provide a high level of scientific and technological development of Ukraine. At the same time, the predominant sources of growth in the industrial sphere of agribusiness so far were the reserves of production capacity and external economic environment favorable for export of agricultural raw materials.

The maintaining of existing tendencies in the agroindustrial sector of the country based on low-tech production, as well as the continuing decline of production in agro-industrial complexes, proves the necessity of applying scientific approaches to research the activities of agroholdings [1]. At the current stage one of the priorities of state policy must be the modernization of 
both the whole national industry, in particular, its processing industry, on the basis of intensification of external policy on the world agricultural products ' market in the conditions of globalization, and the most effective use of its powerful scientific and technological potential.

\section{Literature review and problem statement.}

This problem is no less relevant to the world community as well. For the development of external policy in the world products market, the activity of agricultural holdings in the economic development of any country seems to be extremely important. Thus, in 1977, the special commission of the US Senate made conclusions about the prospects for the development of science and technology, which would be given more attention than any other component of national policy or national programs [2]. "In advanced countries, the development and implementation of technological innovation is a determining factor in social and economic development, a guarantee of economic security. For example, in the United States, the growth of national income per capita due to this factor in recent years is up to $90 \%$ "[3].

In January 2003 in Helsinki, at the initiative of the Parliament of Finland, as well as UNESCO and ISESCO, there was a round table discussion "Science, Technology and Innovation Policy: Parliamentary Perspectives" with participation of the parliaments representatives of Europe, Asia, Africa and America. Based on the work of the meeting, the participants approved the Helsinki Declaration, which is an appeal to world parliamentarians. This Declaration states that the main criterion of success is the development of national innovation systems, the validity of external policy in the global market for the production of agricultural holdings in the context of globalization.

Recently, labor-intensive and technologically obsolete factories, which pollute the environment, must be reconstructed. In addition, the crisis and competition in the international and domestic markets of agricultural production are escalating. This causes increasing attention to international agricultural enterprises, agroholdings and other agribusiness organizations, to their activity concerning the supply of their products to world markets, as only its results can give the opportunity to produce goods, which meet the growing competitive demands in the global markets in a globalized world [4].

In addition, the requirement to increase the efficiency of the investment resources used, as well as the desire to receive high profits, encourages the processing industries to develop agroholdings, which require acceleration and effective management of their production. In Ukraine, the development of agroholdings in different periods had a tendency to both growth and decline, but in recent years, there has been an increase in the share of international processing agribusinesses $[5,6]$.

An important strategic direction of Ukraine is the development of the activity of agroholdings in the conditions of globalization $[7,8]$. The achievements of Ukrainian economy competitiveness where production and sevices' competitiveness of domestic enterprises on the external and internal markets has a special role, is one of the main tasks of economics. An important element of competitiveness is innovation, which in recent years has become crucial for the development of agrarian production in a social system based on the knowledge gained and information resources.

The solution of the food security problem in Ukraine is a national task that is directly related to the development of the activities of agroholdings [9-11]. Ukraine has declared the choosing of an innovative way of its development a lot time ago. A large number of legislative and normative documents have been approved to implement this program. Also specialists are actively working on the issue of reorganization in government bodies, hold conferences, forums and public discussions, consider the problems of innovations in numerous publications. But the main thing is the launch of real mechanisms of innovation development, which will work in each branch of the national economy, taking into account national priorities and trends of world development of scientific and technological progress [12].

\section{The aim and objectives of the study.}

Analyzing of the tendencies of development of agroholdings and other agroformations in modern socio-economic conditions. In order to study the mechanism of their development constructing models of interconnection between the components of production of the main types of products of agricultural holdings and the availability of agricultural raw materials.

\section{Substantial statement of the problem.}

Nowadays, in the structure of Ukraine's exports, the share of exports of metals, minerals and chemical products accounts for about $60 \%$ of its volume, which suggests that the gross domestic product (GDP) of the country largely depends on fluctuations in world prices for metals, minerals etc. [13-15]. To increase the GDP (gross domestic product), it is necessary to diversify the exported products, which relate mainly to the agro-industrial complex of the country. In addition, according to FAO (Food and Agriculture Organization) estimates, by 2050, global population growth is expected to reach 9.1 billion. Population growth will come mainly from countries that are developing with accelerated urbanization, which will lead to increased demand for food [16]. The global challenge for the processing industry of the agroindustrial complex in the aspect of constant population growth is to increase production by at least $70 \%$. This was stated by Jean-Jacques Hervé, Advisor to 
the Board of PJSC "Credit Agricole Bank" (Credit Agricole), during a round table discussion "Introduction of new technologies: challenges for Ukrainian companies" [17].

At the opening of the International Investment Forum in Kirovohrad, which took place in October 2016, it was noted that a significant share of the country's GDP was formed in the agricultural sector, and the uniqueness of the resource base of the industry creates virtually unlimited potential for its economic growth. It was also noted that agrarian production is one of the priority issues in investing [18]. At the same time, Ukraine has a huge "agrarian" potential. For example, black earth, convenient geographical location for export markets, deep-sea ports, developed infrastructure, which is a large and powerful foundation for the development of a competitive agrarian sector, including its processing sub-sector, which is one of the sources of growth and development of the economy and raising the standard of living of the country's population [19].

To quantitative study the factors of influence on the activity of agricultural holdings, we will determine the dependence of the indicators of products of processing enterprises and components of agricultural production, providing on the availability of raw materials of processing enterprises, namely, the indicator of the efficiency of production of raw material of plant growing $\left(y_{1}\right)$, the efficiency of production of livestock raw materials $\left(y_{2}\right)$, and generalizing indicator of the efficiency of production of mixed raw material of plant growing and livestock $\left(\mathrm{y}_{3}\right)$ on components that characterized supply of raw materials of the enterprise). In order to construct a model for estimating the production of agricultural raw materials by the processing enterprises of the agroindustrial complex on the basis of the three reduced performance indicators, a stepwise regression analysis (stepwise regression) of sequential factor exclusion was performed using the Statfield GraphicCenturion statistical step package Module StepwiseVariableSelection based on the data for the period 1990-2016 [20].

The multifactor regression linear model of the evaluation of production of agricultural raw materials, namely, the dependence of the efficiency of production of raw material from crop production (y1) of the thirteen components of agricultural production, has the form:

$$
y_{1}=69.7636+0.00139897 x_{2}+0.153473 x_{5} .
$$

Thus, the dependence of the efficiency of products' production from the raw materials of crop production $\left(y_{1}\right)$ depends only on two components: the average prices for the sale of grain and leguminous crops $\left(x_{5}\right)$, as well as labor productivity in crop production $\left(x_{3}\right)$ and does not depend on other components.

The calculated model of the dependence of the generalized index of the efficiency of crop production on the components of agricultural production is statistically qualitative, as evidenced by the calculated values of the Student's T-Test $\left(t_{b_{0}}=3.4166, t_{b_{0_{12}}}=3.7912, t_{b_{5}}=3.2674\right), \quad$ Fisher Least Significant Difference (LSD) test $(F=7.21)$ and Durbin-Watson Statistics $(D W=1,14)$. The coefficient of determination shows that the variability of the efficiency of production from the raw materials of crop production is explained by $95,0 \%$ by the variability of two significant factors: the average selling prices of grain and leguminous crops $\left(x_{5}\right)$ and labor productivity in crop production $\left(X_{3}\right)$.

The multifactorial regression linear model of the dependence of the production from animal husbandry raw materials $\left(y_{2}\right)$ on the main components is as follows:

$$
y_{2}=-9188.7+0.2184 x_{1}+0.0107 x_{13} .
$$

According to the equation, we can observe that the efficiency of production from animal husbandry materials $\left(y_{2}\right)$ depends on the components: the volume of agricultural raw materials $\left(x_{1}\right)$ and the average prices of livestock and poultry (in live weight) sold by agricultural enterprises $\left(x_{13}\right)$. The calculated model is statistically adequate, as evidenced by the calculated values of the Student's T-Test $\left(t_{b_{0}}=-5.8394, t_{b_{1}}=-5.8199, t_{b_{13}}=-7.4457\right), \quad$ Fisher Least Significant Difference (LSD) test $(F=27.87)$ and Durbin-Watson Statistics $(D W=1.24)$.

The coefficient of determination shows that the variability of the efficiency of production from animal husbandry materials based on time is explained by the $95.0 \%$ variability of two significant factors: the volumes of agricultural raw materials and the average prices of sales by livestock and poultry enterprises (in live weight) by enterprises [21].

The studied multiple regression linear model of the dependence of production of mixed materials of crop and cattle production $\left(\mathrm{y}_{3}\right)$ on the components of agricultural production is as follows:

$$
y_{3}=-10042.7+0.2397 x_{1}+0.0352 x_{8} .
$$

Consequently, the indicator of agricultural production efficiency $(y)$ depends on the volume of agricultural raw materials $\left(x_{1}\right)$ and average prices of oilseeds $\left(x_{8}\right)$ and does not depend on the remaining eleven components of agricultural production. The calculated model is statistically adequate, as evidenced by the calculated values of the Student's T-Test $\left(t_{b_{0}}=-4.5524, t_{b_{1}}=4.5545, t_{b_{8}}=4.5191\right)$, Fisher Least Significant Difference (LSD) test $(F=12.23)$ and Durbin-Watson Statistics $(D W=0.92)$. The coefficient of 
determination shows that the variability of the index of the efficiency of production from agricultural raw materials $(y)$ is explained by $95.0 \%$ of the variability of the volumes of agricultural raw materials and by $87.3 \%$ of the variability of average prices for the sale of oilseeds.

\section{Conclusions and future work.}

So, the conducted research has shown the significance of influence of some factors of raw material agricultural production on the recycling enterprises relying in their activity on the supply of raw materials. Enterprises that use the products of crop production in their production, depend significantly on the average prices of sales of grain and leguminous crops and labor productivity in crop production[22]. Recycling companies specializing in the use of products from animal husbandry materials essentially depend on the volumes of agricultural production and average prices for the sale of livestock and poultry (in live weight) by enterprises. Mixed companies depend on the volumes of agricultural raw materials and the average prices for the sale of oilseeds.

Thus, using the obtained results on the basis of the tool of economic and mathematical modeling, which is based on processing of statistical information of retrospective nature, the evaluation of individual variables and their parameters, the interdependence of the most influential factors of agricultural production was found, and regression models of indicators were calculated on the most significant aggregating factors characterizing the development of the agrarian potential of the Ukrainian economy.

It is a practical tool for making managerial decisions for forecasting tactical and strategic directions of the development of agroholdingsin Ukraine and export of agricultural production to the world commodity markets.

\section{ДІЯЛЬНІСТЬ АГРОХОЛДИНГІВ НА СВІТОВОМУ РИНКУ СІЛЬСЬКОГОСПОДАРСЬКОї ПРОДУКЦІї В КОНТЕКСТІ ГЛОБАЛІЗАЦІї}

Бабенко Віталіна Олексіївна, доктор економічних наук, професор, Харківський національний університет імені В. Н. Каразіна, пл. Свободи, 6, м. Харків, Україна, 61022, e-mail: vitalinababenko@karazin.ua; ORCID: http://orcid.org/0000-0002-4816-4579, ScopusAuthor ID: 56658371300; Researcher ID: E-6521-2018

Сідоров Вадим Ігорович, кандидат економічних наук, професор, Харківський національний університет імені В. Н. Каразіна пл. Свободи, 6, м. Харків, Україна, 61022, e-mail: v.i.sidorov@karazin.ua; ORCID: https://orcid.org/0000-0002-5655-2221

Савін Руслан Сергійович, аспірант, Харківський національний університет імені В. Н. Каразіна, пл. Свободи, 6, м. Харків, Україна, 61022, e-mail: irtb@karazin.ua; ORCID: https://orcid.org/0000-0003-4634-0660

Сучасні процеси реформування агропромислового комплексу України в умовах глобалізації світових економічних процесів на сільськогосподарському ринку вимагають від вітчизняних агрохолдингів поліпшення і раціонального управління їх виробничої діяльності. Тому питання дослідження тенденцій розвитку агрохолдингів та інших агроформувань у сучасних соціально-економічних умовах є актуальними. Для вивчення механізму їх розвитку побудовано моделі взаємозв'язку між компонентами виробництва основних видів продукції агрохолдингів та наявністю сільськогосподарської сировини. Основними підходами є багатомірне регресійне моделювання залежності виробництва агрохолдингів від компонентів сільськогосподарського виробництва. Предметом дослідження є розвиток агрохолдингів. Метою дослідження $€$ вивчення тенденцій розвитку агрохолдингів та інших агросрормувань у сучасних соціально-економічних умовах. Завданням $€$ дослідження динаміки розвитку агрохолдингів України з точки зору її компонентів в умовах глобалізації світових економічних процесів на ринку сільськогосподарської продукції.

Для дослідження використано загальні наукові методи: системний аналіз для визначення особливостей розвитку агропромислового виробництва в Україні; регресійний аналіз для розрахунку залежності виробництва сільськогосподарських господарств від компонентів сільськогосподарського виробництва. Отримано наступні результати: на основі аналізу динаміки змін основних показників вітчизняного сільськогосподарського виробництва було отримано аналітичну взаємозалежність основних фракторів впливу на розвиток агрохолдингів. Висновки: розраховано багатомірна регресійна модель залежності виробництва агрохолдингів від компонентів сільськогосподарського виробництва; отримані результати доцільно використовувати у зовнішньоекономічній діяльності в якості рекомендацій для визначення стратегії України на світовому ринку сільськогосподарської продукції.

Ключові слова: агрохолдинг, світове господарство, агропромислове виробництво, сільськогосподарська продукція, фрактори розвитку, регресійна модель.

\section{ДЕЯТЕЛЬНОСТЬ АГРОХОЛДИНГОВ НА МИРОВОМ РЫНКЕ СЕЛЬСКОХОЗЯЙСТВЕННОЙ ПРОДУКЦИИ} В КОНТЕКСТЕ ГЛОБАЛИЗАЦИИ

Бабенко Виталина Алексеевна, доктор экономических наук, профессор, Харьковский национальный университет имени В. Н. Каразина, пл. Свободы, 6, г. Харьков, Украина, 61022, e-mail: vitalinababenko@karazin.ua; ORCID: http://orcid.org/00000002-4816-4579, Scopus Author ID: 56658371300; ResearcherID: E-6521-2018

Сидоров Вадим Игоревич, кандидат экономических наук, профрессор, Харьковский национальный университет имени В. Н. Каразина, пл. Свободы, 6, г. Харьков, Украина, 61022, e-mail: v.i.sidorov@karazin.ua; ORCID: https://orcid.org/00000002-5655-2221

Савин Руслан Сергеевич, аспирант, Харьковский национальный университет имени В. Н. Каразина, пл. Свободы, 6, г. Харьков, Украина, 61022, e-mail: irtb@karazin.ua; ORCID: https://orcid.org/0000-0003-4634-0660

Современные процессы реформирования агропромышленного комплекса Украины в условиях глобализации мировых экономических процессов на сельскохозяйственном рынке требуют от отечественных агрохолдингов улучшения и рационального управления их производственной деятельности. Поэтому вопросы исследования тенденций развития агрохолдингов и других агроформирований в современных социально-экономических условиях являются актуальными. Для изучения механизма их развития построены модели взаимосвязи между компонентами производства основных видов продукции сельскохозяйственных хозяйств и наличием сельскохозяйственного сырья. Основными подходами являются многомерное регрессионное моделирование зависимости производства сельскохозяйственных хозяйств от компонентов сельскохозяйственного производства. Предметом 104 
исследования в статье является развитие агрохолдингов. Целью исследования является изучение тенденций развития агрохолдингов и других агроформаций в современных социально-экономических условиях. Задача: исследование динамики развития агрохолдингов Украины с точки зрения ее компонентов в условиях глобализации мировых экономических процессов на рынке сельскохозяйственной продукции.

Используются общие научные методы: системный анализ - для определения особенностей развития агропромышленного производства в Украине; регрессионный анализ для расчета зависимости производства сельскохозяйственных хозяйств от компонентов сельскохозяйственного производства. Получены следующие результаты: на основе анализа динамики изменений основных показателей отечественного сельскохозяйственного производства были получены аналитические зависимости факторов, влияющих на процесс развития агрохолдингов. Выводы: рассчитана множественная регрессионная модель зависимости производства агрохолдингов от компонентов сельскохозяйственного производства; полученные результаты целесообразно использовать во внешнеэкономической деятельности в качестве рекомендаций для определения стратегии Украины на мировом рынке сельскохозяйственной продукции.

Ключевые слова: агрохолдинг, мировое хозяйство, агропромышленное производство, сельскохозяйственная продукция, факторы развития, регрессионная модель.

\section{References}

1. Бабенко В.О. Управління інноваційними процесами переробних підприємств АПК (математичне моделювання та інформаційні технології) : моногр. / Харк. нац. аграр. ун-т ім. В. В. Аокучаєва. - Х. : ХНАУ, Х. Мачулин, 2014. - 380 с.

2. Science and Technology [Електроннийресурс] / U.S. Department of State. - Режим доступу: http://www.state.gov.

3. Про проведення парламентських слухань на тему: «Економічна політика України: актуальні питання»: Постанова Верховної Ради України № 1615-ІVвід 18.03.2004 // Відомості Верховної Ради України. - Офіц. вид. 2004. - № 24. - С. 340.

4. Про схвалення Концепції Аержавної цільової економічної програми впровадження в агропромисловому комплексі новітніх технологій виробництва сільськогосподарської продукції на період до 2016 року: розпорядження Кабінету Міністрів України № 1650 від 23 грудня 2009 р. // Офіц. вісн. України. - Офіц. вид. - 2010. № $1-$ Ст. 40.

5. Статистическая информация. Промышленность. Производство основных видов промышленной продукции за 2003 - 2013 гг. [Електронный ресурс] / Госуд. служба статистики Украины. - Режим доступа: http://www.ukrstat.gov.ua.

6. Україна у цифрах: Статистичний збірник / за ред. Осауленка О. Г. Аержавна служба статистики України. - К.: ТОВ Вид-во «Консультант», 2014. - 240 с.

7. Бабенко В. А. Аспекты управления инновационными технологиями в сфере переработки продукции сельскохозяйственного производства / Міжнар. наук.-практ. Інтернет-конф. «Інноваційні технології в харчовій промисловості та ресторанному господарстві» (Харків, 14 - 16 листоп. 2012 р.) / редкол. : О. І. Черевко [та ін.] ; Харк. держ. ун-т харчування та торгівлі. - Х., 2012. - С. $141-144$.

8. Бабенко В. А. Формирование динамической модели многокритериальной оптимизации управления инновационными процессами перерабатывающих предприятий АПК // Бизнес Информ. - 2013. - № 7 . C. 85 - 88.

9. Про основи національної безпеки України: Закон України від 19.06.2003 № 964-IV // Голос України. 2003. - № 134 .

10. Про прийняття за основу проекту Закону України про продовольчу безпеку України: Постанова Верховної Ради України № 3498-VІвід 14.06.2011 [Електронний ресурс]. - Режим доступу: http://w1.c1.rada.gov.ua/pls/ zweb_n/webproc4_2?pf3516=8370-1\&skl=7.

11. Про рішення Ради національної безпеки і оборони України від 9 грудня 2005 року «Про стан агропромислового комплексу та заходи щодо забезпечення продовольчої безпеки України»: Указ Президента України № 1867/2005 від 28.12.2005// Уряд. кур'єр. - Офіц. вид. - 2006. - № 11.

12. Про основні засади державної аграрної політики на період до 2015 року: Закон України від 18.10.2005 № 2982-IV// Голос України. - 2005. - № 217.

13. Аоговір про заснування ЄС: Аиректива 2003/30/ЄС: [Електронний ресурс] / Офіційний вісник Європейських співтовариств. - 17.05.2003. - Режим доступу: http://www.sdla.gov.ua:8080/control/uk.

14. Про затвердження плану заходів з виконання Програми діяльності Кабінету Міністрів України та Стратегії сталого розвитку "Україна-2020" у 2015 році від 04.03.2015 № 213-р Електронний ресурс Режим доступу: http://zakon3.rada.gov.ua/laws/show/213-2015-p/ed20150304.

15. Babenko V., Alisejko E., Kochuyeva Z. The task of minimax adaptive management of innovative processes at an enterprise with risk assessment // Innovative technologies and scientific solutions for industries, 2017. - No. 1 (1). P. 6-13. DOI: https://doi.org/10.30837/2522-9818.2017.1.006

16. Аграрный сектор Украины: инвестиционная привлекательность, несмотря на несовершенное регулирование [Електронный ресурс] / IFC (Международная финансовая корпорация) // АПК-информ. - 2013. - Режим доступа: www.apk-inform.com. 
17. Бабенко В.О. Проблемні аспекти інноваційної діяльності України на світовому ринку сільськогоспоАарської продукції // Науковий вісник Ужгородського національного університету. Сер. «Міжнародні економічні відносини та світове господарство». Вип. 6, ч.1. - 2016. - 177 с. - С. $26-29$.

18. Агровыпуск агрохолдинга «Хармелия» [Електронный ресурс] / Агрохолдинг «Хармелия». - 2013, 4 окт. - Режим доступа: http://www.harmelia.com.

19. Українау цифрах: Статистичний збірник / за ред. Осауленка О. Г. Аержавна служба статистики України. - К.: ТОВ ВиА-во «Консультант», 2014. - 240 с.

20. Babenko V.A. Modelling of factors affecting innovational agricultural activity of enterprises AIC in Ukraine // Scientific bulletin of Polissia. - 2017. - № 1 (9), p. 2. - P. 115-121. DOI: 10.25140/2410-9576-2017-2-2(10)

21. Sidorov V., Babenko V., Bondarenko M. Researching factors of innovative activities of agrarian business of Ukraine under globalization of the world economy // Innovative technologies and scientific solutions for industries, 2017. - No. 2 (2). - P. 70-76. DOI: https://doi.org/10.30837/2522-9818.2017.2.070 